\title{
APC promoter methylation is correlated with development and progression of bladder cancer, but not linked to overall survival: a meta-analysis
}

\author{
Z. J. BAI ${ }^{1}$, Q. LIU' ${ }^{1}$, X. S. WANG ${ }^{1}$, W. Y. LIU', \\ ${ }^{1}$ Department of Urology, Tianjin First Central Hospital, Nankai University, Tianjin, 300192, China; ${ }^{2}$ Department of pathogen Biology, School of \\ Basic Medical Sciences, Tianjin Medical University, Tianjin, 300070, China \\ *Correspondence: liuweiying3@126.com
}

Received October 9, 2018 / Accepted December 19, 2018

\begin{abstract}
The clinical role of APC promoter methylation in patients with bladder cancer remains to be determined. The relevant databases (PubMed, EMBASE, EBSCO, WANFANG DATA, CNKI and Cochrane Library) were searched to get eligible studies. The overall odds ratios (ORs) and the corresponding 95\% confidence intervals (95\% CIs) were calculated to assess the effects of $A P C$ promoter methylation on bladder cancer risk and clinicopathological features. 2214 patients with bladder cancer and 665 controls were identified. APC promoter methylation was significantly higher in bladder cancer than in non-malignant tissue and urine samples (tissue: $\mathrm{OR}=11.14,95 \% \mathrm{CI}=4.29-28.91, \mathrm{p}<0.001$; urine: $\mathrm{OR}=24.31,95 \% \mathrm{CI}=6.26-$ 94.38, $\mathrm{p}<0.001)$, but not in blood samples $(\mathrm{p}=0.242)$. The relationship was observed between APC promoter methylation and gender (male vs. female: $\mathrm{OR}=1.46,95 \% \mathrm{CI}=0.96-2.22, \mathrm{p}=0.074$ ), tumor stage (stage $\mathrm{T} 2-\mathrm{T} 4 \mathrm{vs}$. Ta-T1: $\mathrm{OR}=3.00,95 \%$ $\mathrm{CI}=1.66-5.42, \mathrm{p}<0.001$ ), and tumor grade (grade $3-4$ vs. grade $1-2: \mathrm{OR}=1.99,95 \% \mathrm{CI}=1.15-3.42, \mathrm{p}=0.013$ ). But no correlation was found between APC promoter methylation and age, lymph node status, and tumor number $(\mathrm{p}>0.1)$. APC gene was not associated with overall survival of bladder cancer patients. Our findings indicate that $A P C$ promoter methylation may be associated with the development and progression of bladder cancer and may serve as a promising non-invasive biomarker using urine samples for the detection of bladder cancer.
\end{abstract}

Key words: APC, methylation, bladder cancer, urine, biomarker, prognosis

Bladder cancer is the most frequent malignant tumor of urinary system diseases [1]. According to GLOBOCAN estimates, approximately 429,800 cases with bladder cancer were diagnosed, leading to an estimated 165,100 deaths in 2012 worldwide [2]. About $75 \%$ of all cases are diagnosed with non-muscle invasive bladder cancer (NMIBC: stage pTa-T1), with a favorable five-year survival rate. While patients with muscle-invasive bladder cancer (MIBC: stage pT2-T4) have a five-year survival rate of less than $50 \%$ because of the high frequency of metastases [3-5].

DNA methylation, a common epigenetic modification, plays an important role in the early phase of carcinogenesis [6-8]. Promoter methylation of tumor suppressor genes (TSGs) has been shown to be involved in the tumorigenesis, progression, and prognosis of various types of human cancers [9-11]. Aberrantly methylated TSGs can be applied as potential diagnostic biomarkers for the detection of cancer $[12,13]$. As a TSG, the adenomatous polyposis coli $(A P C)$ gene, encoding a large multidomain protein, is mapped to human chromosome band 5q21 [14, 15]. The APC gene participates in some biolog- ical functions, such as WNT signaling, cell migration and adhesion, cell differentiation and proliferation, transcriptional activation, and apoptosis [16-18]. APC promoter methylation has been found in different sample types of bladder cancer, including tissue, urine, and blood samples [19, 20].

However, a small number of participants regarding APC promoter methylation may lack strong statistical power in bladder cancer [21, 22]. Therefore, we systematically integrated all eligible publications to determine whether APC promoter methylation was correlated with bladder cancer in tissue, urine, and blood samples. In addition, we also determined the correlation between APC promoter methylation and clinicopathological characteristics of patients with bladder cancer.

\section{Materials and methods}

Literature search strategy. Two authors conducted a systematic literature search (PubMed, EMBASE, EBSCO, WANFANG DATA, CNKI and Cochrane Library databases) to 
identify studies before June 3, 2017. We used the following terms during the search: (adenomatous polyposis coli OR APC) AND (bladder cancer OR bladder tumor OR bladder carcinoma OR bladder neoplasm) AND (methylation OR epigene ${ }^{*}$ OR methylated OR hypermethylation). We also conducted a manual search of the reference lists from the eligible publications for other additional studies.

Inclusion criteria. Studies had to meet the following selection criteria in the meta-analysis: 1) patients were diagnosed with primary bladder cancer; 2) sample type consisted of tissue, urine and blood samples from bladder cancer patients and corresponding non-tumor controls; 3) Studies had sufficient data to evaluate the correlation between APC promoter methylation and bladder cancer in cancer vs. non-tumor controls, and to the clinicopathological features of patients with bladder cancer; 4) studies provided sufficient information on the prognosis if possible. Only the most complete publication with sufficient information was included in this meta-analysis when authors published several papers using duplicated data.

Data extraction and quality assessment. For the eligible studies, two authors independently checked and extracted the following data: first author's surname, publication year, country, race, tumor stage, sample type (tissue, urine, and blood), detection method of methylation, number of participants, methylation level, clinicopathological parameters (gender: male vs. female, age: $\geq 60$ years vs. $<60$ years, tumor grade: grade 3-4 vs. grade 1-2, lymph node status: positive vs. negative, tumor stage: T2-4 vs. Ta-1, and tumor number: single vs. multiple), and survival information. Disagreements were resolved by consensus from all authors. In addition, the Newcastle-Ottawa Scale (NOS) for case-control or cohort design was used to assess the quality of the eligible studies [23], including three parameters: selection (0-4), comparability $(0-2)$, and outcome or exposure assessment $(0-3)$. The scores of quality assessment ranged from 0 to 9 for each study, the study with scores $\geq 6$ was considered as high quality. The study got a score $\leq 5$, which was considered as low quality [24].

Statistical analysis. Data analysis was conducted using the Stata software (version 12.0, Stata Corporation, College Station, TX, USA). The relationship of APC promoter methylation between bladder cancer and non-tumor controls, and the association between APC promoter methylation and clinicopathological characteristics of patients with bladder cancer were calculated by the pooled odds ratios (ORs) with corresponding 95\% confidence intervals (95\% CIs). The overall hazard ratio (HR) with $95 \% \mathrm{CI}$ was used to evaluate the prognostic role of $A P C$ promoter methylation if possible. According to the Cochran's $\mathrm{Q}$ test and $\mathrm{I}^{2}$ statistic, betweenstudy heterogeneity was applied in the meta-analysis [25]. The random-effects model was selected in the current metaanalysis. When cancer was compared to nonmalignant

Table 1. The basic characteristics of the eligible articles.

\begin{tabular}{|c|c|c|c|c|c|c|c|c|c|c|c|}
\hline First author & Country & Stage & Ethnicity & Age & Method & Sample & $\begin{array}{c}\text { Cancer } \\
\text { Total (M \%) }\end{array}$ & $\begin{array}{c}\text { Controls } \\
\text { Total (M \%) }\end{array}$ & $\begin{array}{l}\text { Clinical } \\
\text { features }\end{array}$ & $\begin{array}{c}\text { MA } \\
\text { (survival) }\end{array}$ & NOS \\
\hline Maruyama $2001[38]$ & USA & $\mathrm{Ta}-\mathrm{T} 4$ & Caucasians & 72 & MSP & Tissue & $98(34.7)$ & NA & Yes & Yes & 9 \\
\hline Dulaimi 2004 [37] & USA & $\mathrm{Ta}-\mathrm{T} 4$ & Caucasians & $37-85$ & MSP & Tissue & $45(68.9)$ & $5(0)$ & Yes & NA & 7 \\
\hline Dulaimi 2004 [37] & USA & $\mathrm{Ta}-\mathrm{T} 4$ & Caucasians & $37-85$ & MSP & Urine & $45(55.6)$ & $21(0)$ & Yes & NA & 7 \\
\hline Yates 2006 [36] & UK & $\mathrm{Ta}-\mathrm{T} 4$ & Caucasians & 75 & QMSP & Urine & $35(40)$ & $69(15.9)$ & No & NA & 8 \\
\hline Neuhausen 2006 [35] & Germany & $\mathrm{Ta}-\mathrm{T} 4$ & Caucasians & 68 & MSP & Tissue & $96(44.8)$ & $19(26.3)$ & Yes & NA & 7 \\
\hline Pu 2006 [22] & USA & NA & Caucasians & NA & MMSP & Tissue & $22(31.8)$ & $11(18.2)$ & No & NA & 6 \\
\hline Pu 2006 [22] & USA & NA & Caucasians & NA & MMSP & Urine & $39(61.5)$ & $10(10)$ & No & NA & 6 \\
\hline Yates 2007 [34] & UK & $\mathrm{Ta}-\mathrm{T} 4$ & Caucasians & 77 & QMSP & Tissue & $96(31.3)$ & $30(3.3)$ & No & NA & 8 \\
\hline Ellinger 2008 [33] & Germany & $\mathrm{Ta}-\mathrm{T} 4$ & Caucasians & $40-86$ & * & Blood & $45(60)$ & $45(0)$ & No & NA & 9 \\
\hline Renard 2010 [32] & Belgium & NA & Caucasians & NA & MSP & Tissue & $91(50.5)$ & $39(0)$ & No & NA & 8 \\
\hline Pan 2010 [39] & China & $\mathrm{Ta}-\mathrm{T} 4$ & Asians & 62.5 & MSP & Tissue & $110(82.7)$ & $15(20)$ & Yes & NA & 6 \\
\hline Eissa 2011 [29] & Egypt & $\mathrm{T} 1-\mathrm{T} 4$ & Caucasians & 60 & MSP & Urine & $210(59.5)$ & $110(2.7)$ & Yes & NA & 8 \\
\hline Serizawa 2011 [31] & Denmark & $\mathrm{Ta}-\mathrm{T} 3$ & Caucasians & NA & MethyLight & Urine & $113(27.4)$ & $33(0)$ & No & NA & 9 \\
\hline Serizawa 2011 [31] & Denmark & $\mathrm{Ta}-\mathrm{T} 3$ & Caucasians & NA & MethyLight & Tissue & $105(30.5)$ & NA & Yes & NA & 9 \\
\hline Chen 2011 [30] & China & $>\mathrm{Ta}$ & Asians & NA & MSP & Tissue & $210(35.7)$ & $2(0)$ & Yes & NA & 6 \\
\hline Berrada 2012 [21] & Morocco & $\mathrm{Ta}-\mathrm{T} 4$ & Caucasians & NA & MSP & Tissue & $29(100)$ & $3(33.3)$ & Yes & NA & 6 \\
\hline Berrada 2012 [21] & Morocco & $\mathrm{Ta}-\mathrm{T} 4$ & Caucasians & NA & MSP & urine & $29(79.3)$ & $3(0)$ & Yes & NA & 6 \\
\hline Hauser 2013 [20] & Germany & $\mathrm{Ta}-\mathrm{T} 4$ & Caucasians & $38-94$ & MSP & Blood & $95(54.7)$ & $132(34.8)$ & No & NA & 8 \\
\hline Bilgrami 2014 [28] & Pakistan & $>\mathrm{Ta}$ & Caucasians & $50-73$ & MSP & Tissue & $76(71.1)$ & $10(0)$ & Yes & NA & 7 \\
\hline Pietrusiński 2017 [19] & Poland & $\mathrm{Ta}-\mathrm{T} 4$ & Caucasians & 66 & MSP & Urine & $113(46)$ & $100(0)$ & Yes & NA & 8 \\
\hline Pietrusiński 2017 [19] & Poland & $\mathrm{Ta}-\mathrm{T} 4$ & Caucasians & 66 & MSP & Tissue & $113(54)$ & $8(0)$ & No & NA & 7 \\
\hline
\end{tabular}

NA: not applicable; MSP: methylation-specific polymerase chain reaction; QMSP: quantitative methylation-specific polymerase chain reaction; MMSP: multiplex methylation-specific polymerase chain reaction; “*” stands for quantitative, methylation sensitive polymerase chain reaction; M: methylation; MA: multivariate analysis; NOS: Newcastle-Ottawa scale. 
controls, significant heterogeneity $(p<0.1)$ was detected, we performed a sensitivity analysis to assess the influence of one study on the results by deleting an individual study [26]. In the current study, publication bias was estimated using Egger's test for the results with greater than or equal to ten studies (cancer vs. nonmalignant tissues, clinical stage, and tumor grade) [27].

\section{Results}

Characteristics of the included studies. Figure 1 depicts the procedure of the described literature search method. According to the inclusion criteria as described above, 16 eligible articles published from 2001 to 2017 [19-22, 28-34, 35-39], involving 1815 cases and 665 controls were identified in the present meta-analysis. Among the include papers, ten studies evaluated the correlation between APC promoter methylation and tissue samples of bladder cancer in cancer vs. nonmalignant controls [19-22, 28, 30, 32, 34, 35, 37, 39]. Seven studies evaluated the association between $A P C$ promoter methylation and urine samples of bladder cancer in cancer vs. nonmalignant controls [19-22, 29, 31, 36, 37]. Two studies estimated the association between $A P C$ promoter methylation and blood samples of bladder cancer in cancer vs. nonmalignant controls [20,33]. Ten articles analyzed the relationship of APC promoter methylation with clinicopathological parameters of patients with bladder cancer [19, 21, 28-31, 35, 37-39], including gender, age, tumor grade, lymph node status, tumor stage, and tumor number. The NOS results showed that the eligible studies were of high quality. The general characteristics of the included publications are listed in Table 1 and Table S1.
Correlation between $A P C$ promoter methylation and bladder cancer. The data involving 888 bladder cancer and 142 nonmalignant tissue samples showed that the frequency of $A P C$ promoter methylation in bladder cancer was higher than in nonmalignant tissue samples $(\mathrm{OR}=11.14,95 \%$ $\mathrm{CI}=4.29-28.91, \mathrm{p}<0.001$, Figure 2).

Figure 2 shows the results of urine ( 584 bladder cancer and 346 nonmalignant controls) and blood (140 bladder cancer and 177 nonmalignant controls) samples, we found that APC promoter methylation was correlated with bladder cancer in the urine $(\mathrm{OR}=24.31,95 \% \mathrm{CI}=6.26-94.38, \mathrm{p}<0.001)$, but not in the blood ( $\mathrm{OR}=14.32,95 \% \mathrm{CI}=0.17-1233.02, \mathrm{p}=0.242)$. Based on the small sample size, the result of the blood should be cautious.

Subgroup analyses in cancer vs. controls. In the comparison of bladder cancer and nonmalignant tissue samples, subgroup analyses based on ethnicity (Caucasians and Asians) and detection method (MSP and non-MSP) were conducted to find the difference among different subgroups (Table 2). Subgroup analysis of ethnic population demonstrated the correlation between APC promoter methylation and ethnic subgroups (Caucasians: $\mathrm{OR}=12.36,95 \% \mathrm{CI}=3.72-41.05$, $\mathrm{p}<0.001$; Asians: $\mathrm{OR}=11.94,95 \% \mathrm{CI}=2.30-61.89, \mathrm{p}=0.003)$. Subgroup analysis based on testing method showed that $A P C$ promoter methylation was associated with bladder cancer in the MSP method $(\mathrm{OR}=15.05,95 \% \mathrm{CI}=4.69-48.26, \mathrm{p}<0.001)$, but not in the non-MSP subgroup $(\mathrm{OR}=4.93$, 95\% $\mathrm{CI}=0.75-$ 32.32, $\mathrm{p}=0.096$ ).

In the comparison of bladder cancer and nonmalignant urine samples, subgroup analysis of testing method demonstrated that $A P C$ promoter methylation was associated with bladder cancer in the MSP and non-MSP subgroups

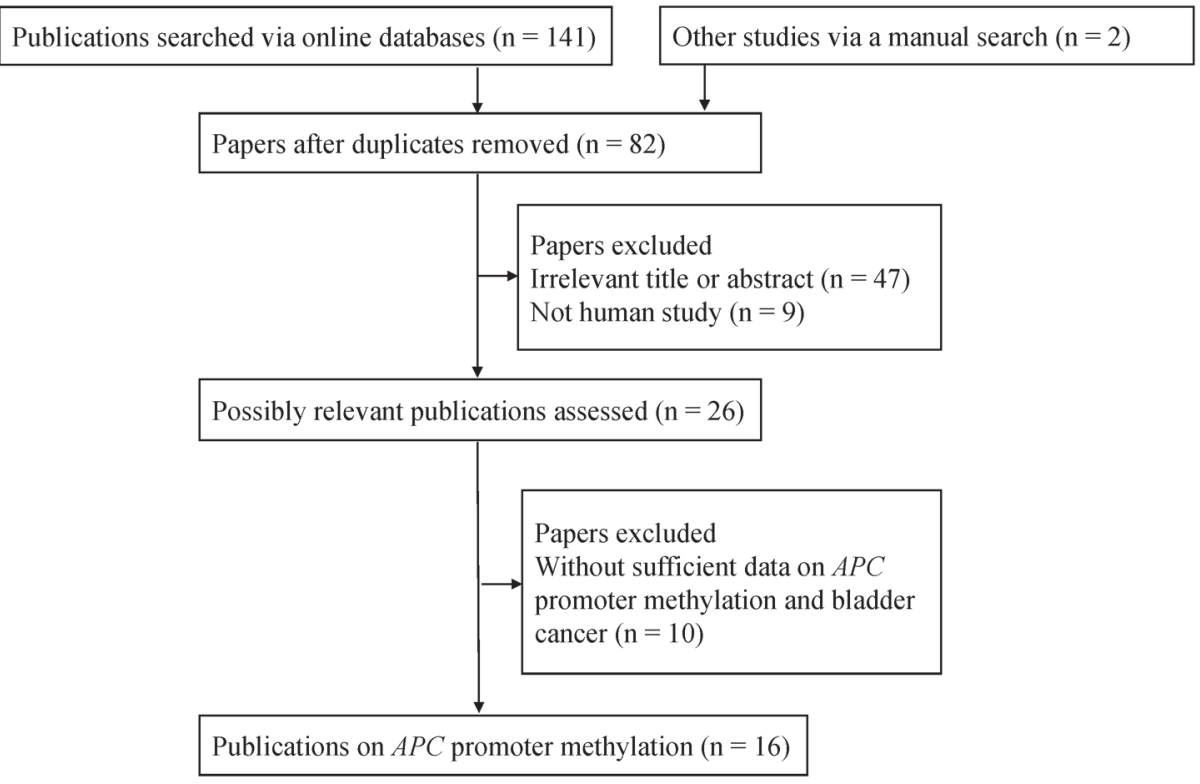

Figure 1. Flow diagram of the procedure of the literature search. 
Table 2. Subgroup analyses in bladder cancer vs. nonmalignant controls.

\begin{tabular}{|c|c|c|c|c|c|}
\hline Tissue samples & OR $(95 \% \mathrm{CI})$ & Heterogeneity: p-value & p-value & Cases & Controls \\
\hline \multicolumn{6}{|c|}{ Detection method } \\
\hline MSP & $15.05(4.69-48.26)$ & 0.041 & $<0.001$ & 770 & 101 \\
\hline Non-MSP & $4.93(0.75-32.32)$ & 0.163 & 0.096 & 118 & 41 \\
\hline \multicolumn{6}{|l|}{ Ethnicity } \\
\hline Caucasians & $12.36(3.72-41.05)$ & 0.029 & $<0.001$ & 568 & 125 \\
\hline Asians & $11.94(2.30-61.89)$ & 0.252 & 0.003 & 320 & 17 \\
\hline \multicolumn{6}{|l|}{ Urine samples } \\
\hline \multicolumn{6}{|c|}{ Detection method } \\
\hline MSP & $56.35(21.45-148.00)$ & 0.811 & $<0.001$ & 397 & 234 \\
\hline Non-MSP & $7.14(1.88-27.20)$ & 0.195 & 0.004 & 187 & 112 \\
\hline
\end{tabular}

MSP: methylation-specific polymerase chain reaction; OR: odds ratios; 95\% CI: 95\% confidence interval.

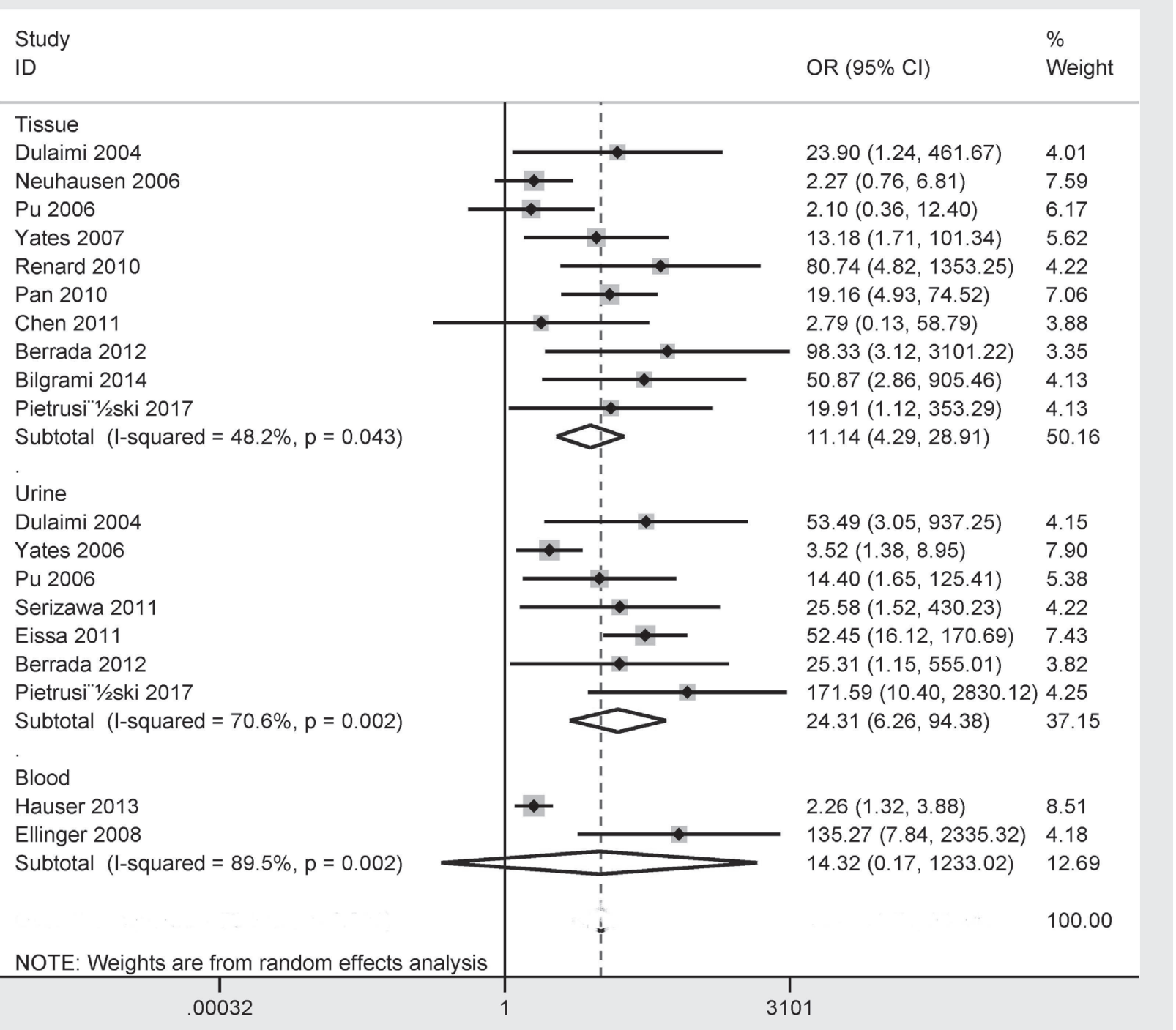

Figure 2. Forest plot indicating the correlation between $A P C$ promoter methylation and bladder cancer in cancer vs. nonmalignant controls, tissue: $O R=11.14,95 \% C I=4.29-28.91, p<0.001$; urine: $O R=24.31,95 \% \mathrm{CI}=6.26-94.38, \mathrm{p}<0.001$; blood: $\mathrm{p}=0.242$. 
$(\mathrm{OR}=56.35,95 \% \mathrm{CI}=21.45-148.00, \mathrm{p}<0.001 ; \mathrm{OR}=7.14,95 \%$ $\mathrm{CI}=1.88-27.20, \mathrm{p}=0.004$; respectively).

Correlation of $A P C$ promoter methylation with gender and age of bladder cancer patients. No significant correlation was found between $A P C$ promoter methylation and age $(\mathrm{OR}=0.87,95 \% \mathrm{CI}=0.29-2.62, \mathrm{p}=0.8)$, including 347 patients with bladder cancer (Figure 3 ). Figure 3 shows that $A P C$ promoter methylation had a trend toward a higher level in male patients with bladder cancer than in female patients with bladder cancer $(\mathrm{OR}=1.46,95 \% \mathrm{CI}=0.96-2.22, \mathrm{p}=0.074)$, including 573 bladder cancer patients.

Correlation of $A P C$ promoter methylation with tumor grade and lymph node status of bladder cancer patients. The data including 870 patients with bladder cancer revealed that $A P C$ promoter methylation was linked to tumor grade $(\mathrm{OR}=1.99,95 \% \mathrm{CI}=1.15-3.42, \mathrm{p}=0.013)$ (Figure 4). The data including 296 patients with bladder cancer revealed that no significant relationship was observed between $A P C$ promoter methylation and lymph node status $(\mathrm{OR}=1.67,95 \% \mathrm{CI}=0.86-$ 3.27, $\mathrm{p}=0.132$, Figure 4).

Correlation of $A P C$ promoter methylation with clinical stage and tumor number of bladder cancer patients. A significant relationship was found between $A P C$ promoter methylation and tumor stage $(\mathrm{OR}=3.00,95 \% \mathrm{CI}=1.66-5.42$, $\mathrm{p}<0.001$ ), including 1064 bladder cancer patients (Figure 5). No significant correlation was found between APC promoter methylation and tumor number $(\mathrm{OR}=0.73,95 \% \mathrm{CI}=0.32-$ 1.66, $\mathrm{p}=0.456)$, including 214 bladder cancer patients (Figure 5).

Prognostic effect. Only one study with 98 patients with bladder cancer reported that $A P C$ promoter methylation was not associated with overall survival of patients [38]. Further

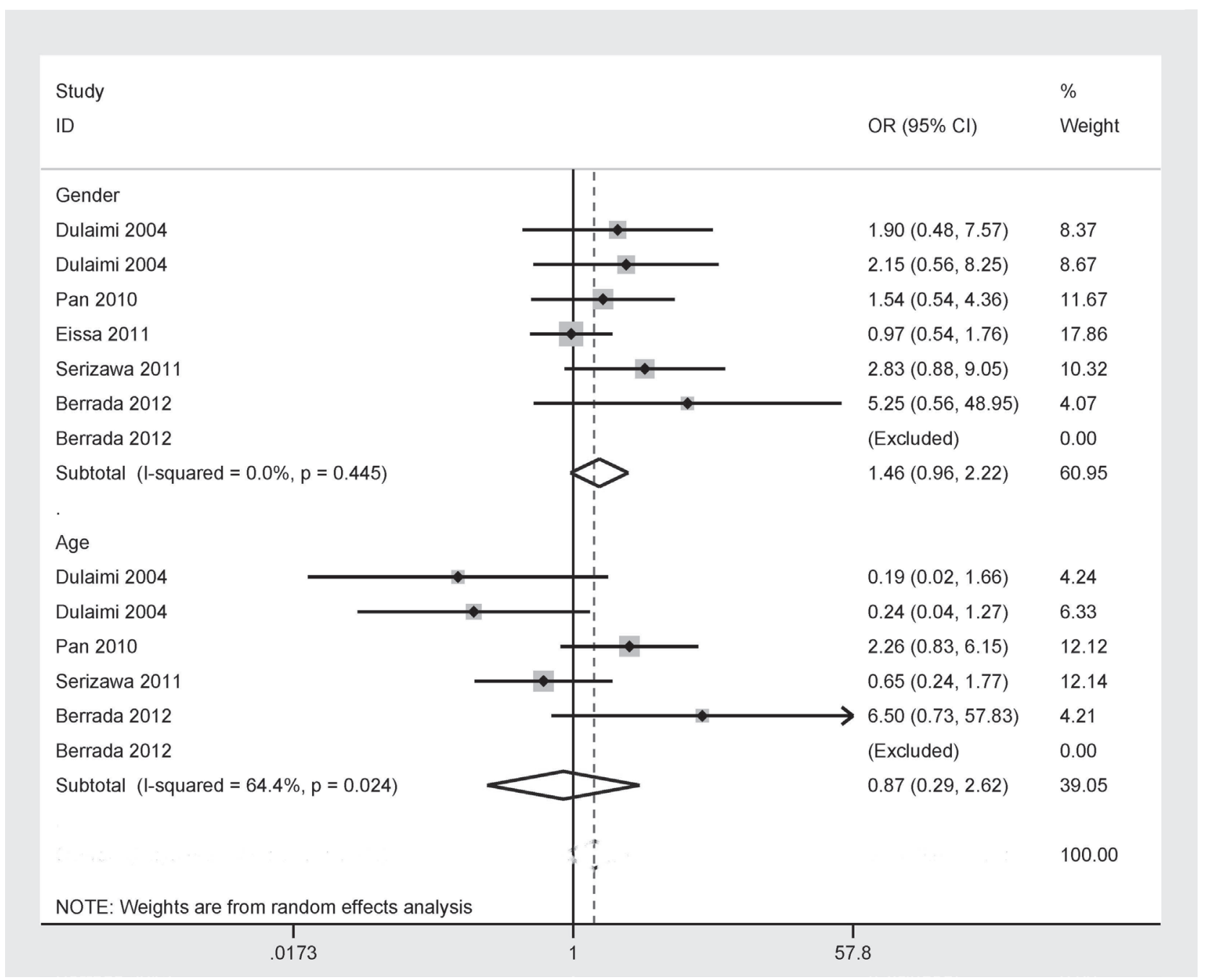

Figure 3. Forest plot of the association between $A P C$ promoter methylation and gender and age of bladder cancer patients, age ( $\geq 60$ years vs. $<60$ years): $\mathrm{OR}=0.87,95 \% \mathrm{CI}=0.29-2.62, \mathrm{p}=0.8$; gender (male vs. female): $\mathrm{OR}=1.46,95 \% \mathrm{CI}=0.96-2.22, \mathrm{p}=0.074$. 


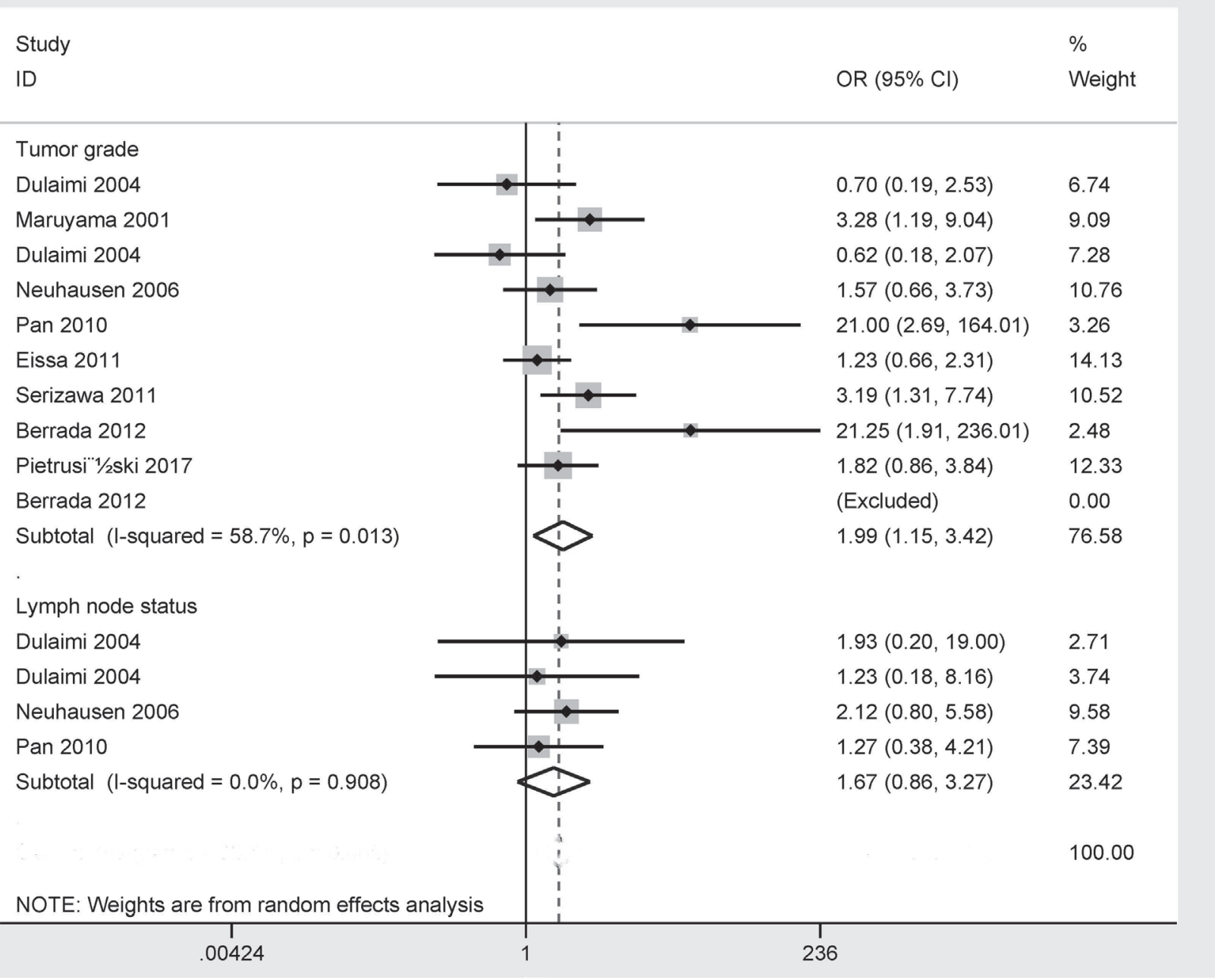

Figure 4. Forest plot of the association between $A P C$ promoter methylation and tumor grade and lymph node status of bladder cancer patients, tumor grade (grade 3-4 vs. $1-2$ ): $\mathrm{OR}=1.99,95 \% \mathrm{CI}=1.15-3.42, \mathrm{p}=0.013$; lymph node status (positive vs. negative): $\mathrm{OR}=1.67,95 \% \mathrm{CI}=0.86-3.27, \mathrm{p}=0.132$.

analysis from Gene Expression Profiling Interactive Analysis (GEPIA) database was performed in 399 bladder cancer patients [40], the result showed that APC expression was not associated with overall survival of bladder cancer $(\mathrm{p}>0.1$, Figure 6).

Sensitivity analysis in cancer vs. controls. We conducted a sensitivity analysis to determine the change of the overall OR and heterogeneity by omitting an individual study in cancer vs. nonmalignant tissues and nonmalignant blood samples $(\mathrm{p}=0.043, \mathrm{p}=0.002$, respectively). When bladder cancer was compared to nonmalignant tissues, one study ([35]) was removed, we re-calculated the overall $\mathrm{OR}(\mathrm{OR}=14.67,95 \%$ $\mathrm{CI}=6.26-34.39, \mathrm{p}<0.001)$, resulting in a decreased heterogeneity $(\mathrm{p}=0.299>0.1)$.

When bladder cancer was compared to nonmalignant blood samples, we removed one study ([36]), and re-calcu- lated the pooled $\mathrm{OR}(\mathrm{OR}=42.73,95 \% \mathrm{CI}=18.42-99.15$, $\mathrm{p}<0.001)$, with no evidence of heterogeneity $(\mathrm{p}=0.788)$.

Publication bias. Egger's test was used to detect the possible publication bias in cancer vs. nonmalignant tissues, clinical stage and tumor grade (Figure 7). No obvious evidence of the publication bias was detected in cancer vs. nonmalignant tissues and between $A P C$ promoter methylation and tumor grade ( $\mathrm{p}>0.05)$, a slight publication bias was found between $A P C$ promoter methylation and tumor stage $(\mathrm{p}=0.025)$.

\section{Discussion}

Promoter methylation of TSGs (e.g. MGMT and RASSF1A) leads to loss or dysfunction of tumor related-gene expression, and may drive the process of cancer [41-43]. 


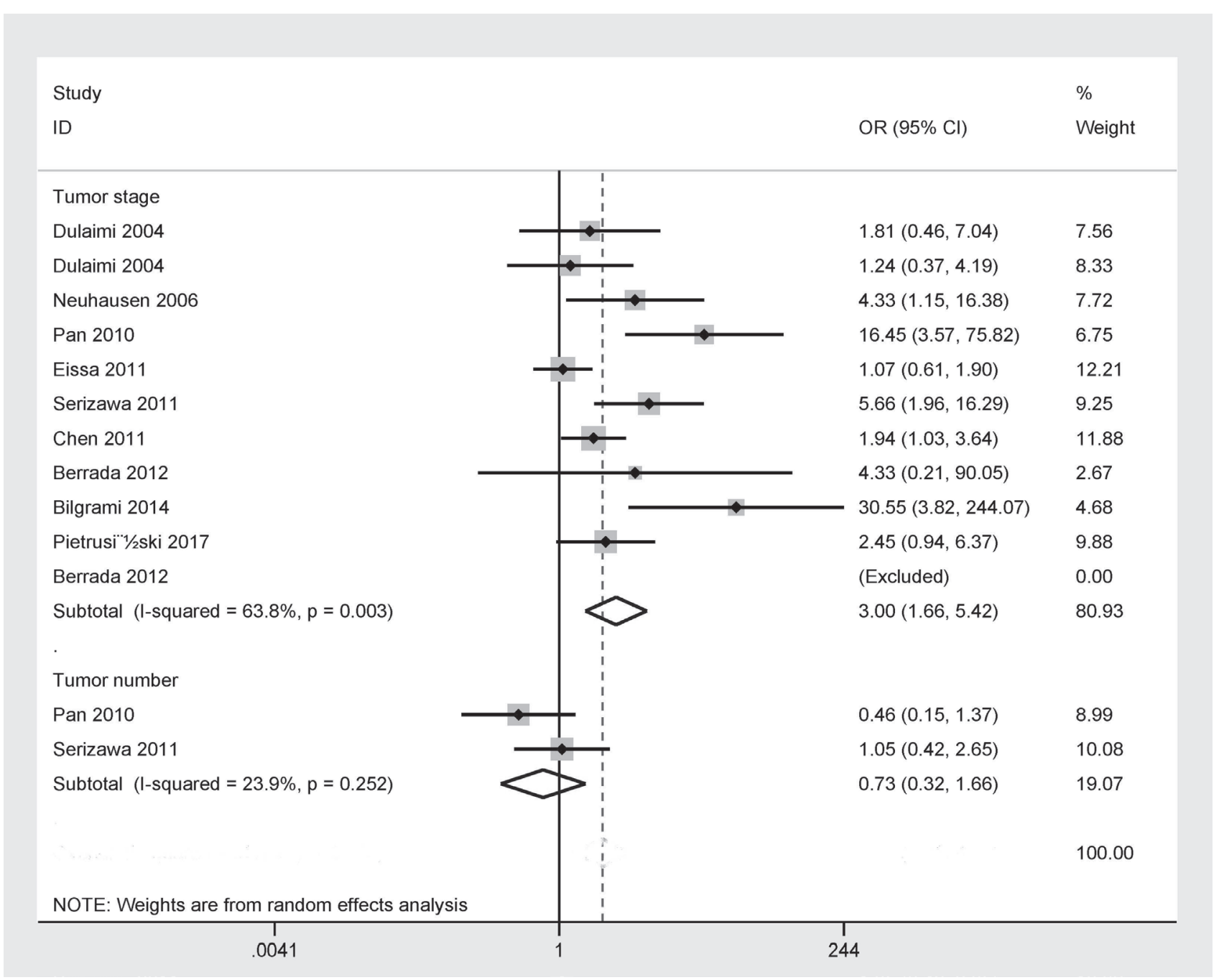

Figure 5. Forest plot of the relationship between APC promoter methylation and clinical stage and tumor number of bladder cancer patients, tumor stage (stage T2-4 vs. Ta-1): $\mathrm{OR}=3.00,95 \% \mathrm{CI}=1.66-5.42, \mathrm{p}<0.001$; tumor number (single vs. multiple): $\mathrm{OR}=0.73,95 \% \mathrm{CI}=0.32-1.66, \mathrm{p}=0.456$.

Additionally, some studies have shown that DNA methylation within the promoter region in bodily fluids (e.g. blood, sputum, and urine etc.) could be used as a promising non-invasive biomarker for the early diagnosis and screening of cancer $[9,12,44,45]$. CDH13 promoter methylation was reported to be correlated with the development and progression of bladder cancer [46]. Dai et al. reported that $D A \mathrm{pK}$ promoter methylation was significantly increased in bladder cancer than in normal controls [47]. Promoter methylation of the $A P C$ gene has been reported in bladder cancer, which suggests that $A P C$ promoter methylation may be linked to the development of bladder cancer, and may become a potential non-invasive biomarker for bladder cancer detection $[19,20$, 28]. However, we found some inconsistent results concerning the methylation frequency of $A P C$ promoter in bladder cancer and non-malignant controls. For example, Yates et al. reported that the frequency of $A P C$ promoter methylation was $31.3 \%$ in tissue samples of bladder cancer and $3.3 \%$ in non-malignant tissues [34]. Berrada et al. reported that APC promoter methylation had a frequency of $100 \%$ in tissue samples of bladder cancer, and a frequency of $33.3 \%$ in non-malignant tissues [21]. Our results comprising more studies with large sample sizes showed that $A P C$ promoter methylation was significantly increased in bladder cancer compared to non-malignant tissue samples, suggesting that $A P C$ promoter methylation was closely correlated with the carcinogenesis of bladder cancer. A further subgroup analysis of ethnicity revealed that promoter methylation of the APC gene was correlated with an increased risk of bladder cancer in the Caucasian and Asian populations. Subgroup analysis of testing method showed that $A P C$ promoter methylation was associated with bladder cancer in the MSP method, 


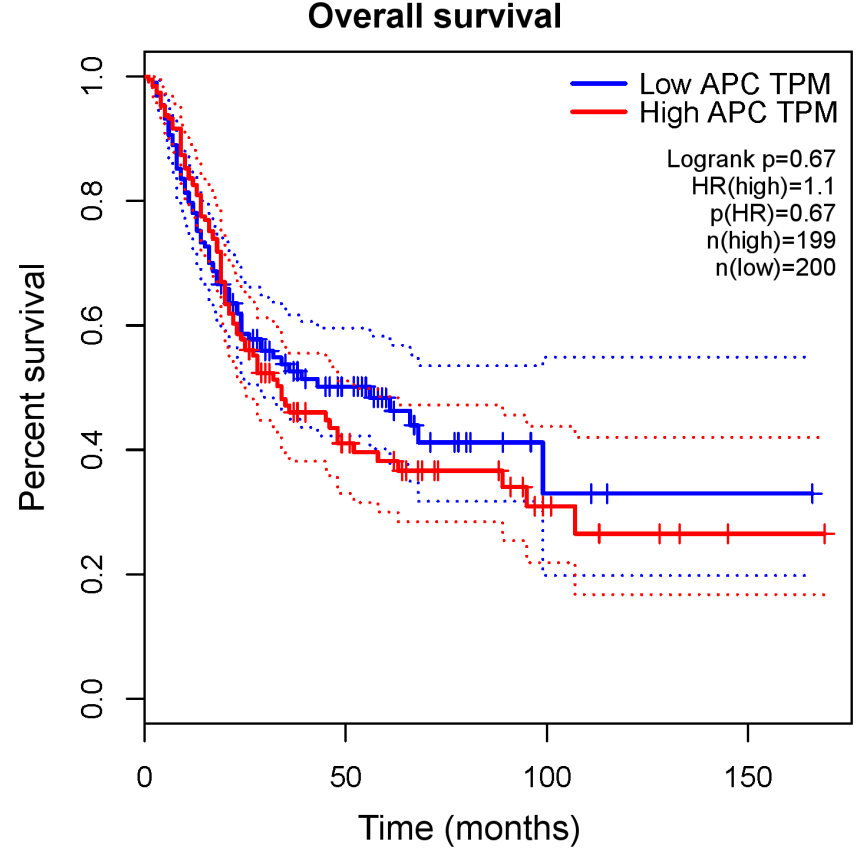

Figure 6. Survival analysis of $A P C$ expression in bladder cancer (overall survival: $\mathrm{p}>\mathbf{0 . 1}$ ).

but not in the non-MSP subgroup. Because the sample size regarding the Asian population and non-MSP subgroup was small, the results should be carefully considered with caution in these two subgroups.

Using patient urine samples, methylated genes such as TWIST1 and NID2 may have utility for the detection of bladder cancer [48-50]. Some studies demonstrated that $A P C$ promoter methylation can be detected in urine or blood samples of patients with bladder cancer [19-21, 33]. Our findings revealed that $A P C$ promoter methylation was significantly associated with bladder cancer using urine samples $(\mathrm{p}<0.001)$, but not correlated with bladder cancer based on blood samples $(\mathrm{p}=0.242)$. Moreover, we found that the OR of urine samples $(\mathrm{OR}=24.31, \mathrm{p}<0.001)$ was higher than the OR of tissue samples $(\mathrm{OR}=11.14, \mathrm{p}<0.001)$, which suggests that $A P C$ promoter methylation based on urine samples may be a useful non-invasive biomarker for the detection of bladder cancer. A further subgroup analysis based on detection method showed that promoter methylation of the APC gene was sensitive to the MSP and non-MSP methods.

Clinically, muscle-invasive or high-grade bladder cancer patients generally have a high incidence of cancer metastasis and unfavorable outcome [4, 51]. We further evaluated whether $A P C$ promoter methylation was correlated with clinicopathological features of bladder cancer. Our results indicated that no relationship was found between APC promoter methylation and age, lymph node status, or tumor number. DNA methylation in bladder cancer may be correlated with increased tumor stage and grade [21]. Some
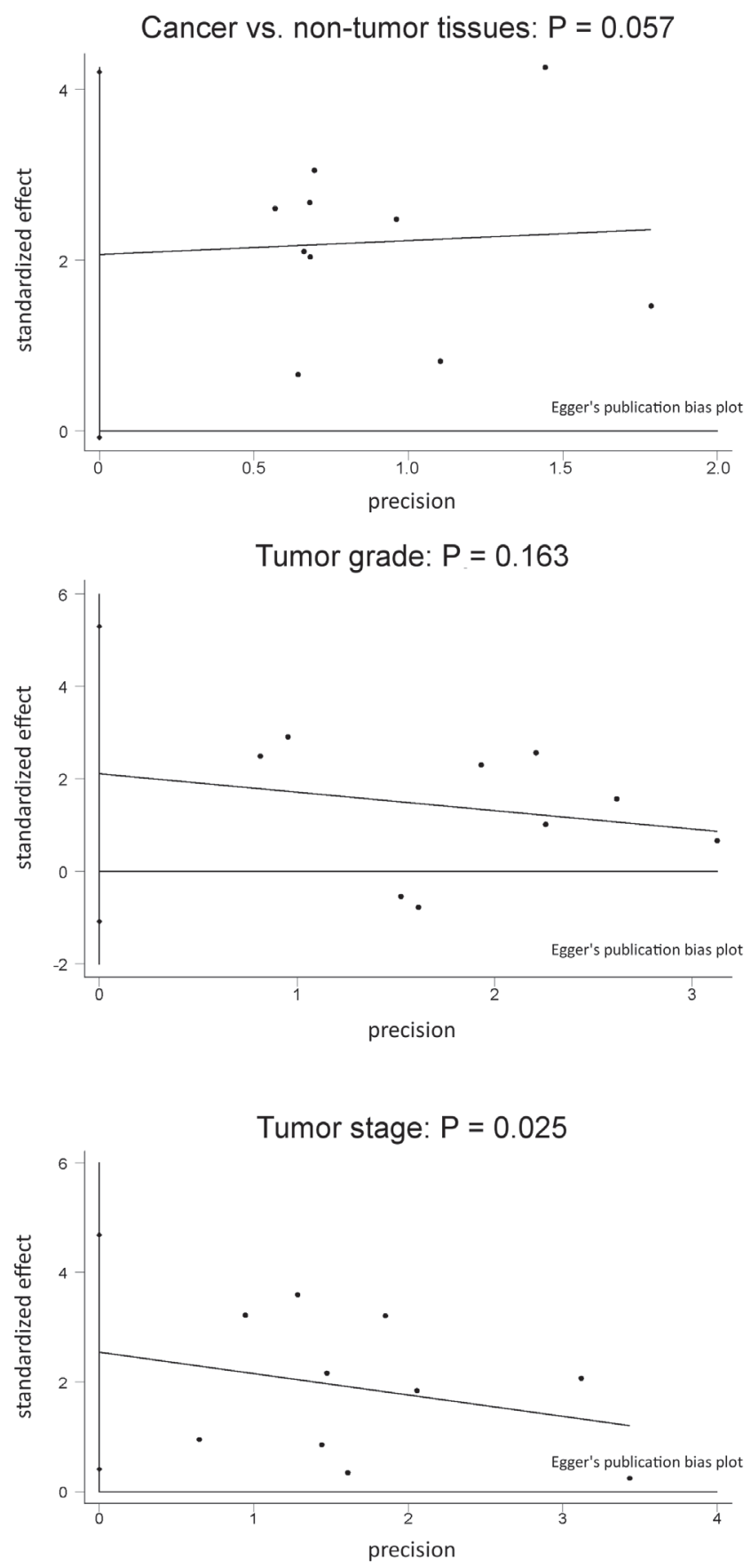

Figure 7. Forest plot of publication bias in cancer vs. nonmalignant tissue samples, clinical stage, and tumor grade.

studies showed that APC promoter methylation was significantly associated with advanced clinicopathological parameters of bladder cancer (tumor grade and stage), suggesting that $A P C$ promoter methylation may be associated with the progression of bladder cancer $[38,39]$. In our study, $A P C$ promoter methylation was found to be positively correlated with tumor stage and tumor grade, which suggests that 
APC promoter methylation may play a key role in bladder cancer progression, and may be a potential biomarker for the prediction of bladder cancer recurrence. Additionally, APC promoter methylation in a large population showed a trend toward higher frequency in male patients with bladder cancer than in female patients with bladder cancer $(\mathrm{OR}=1.46$, 95\% $\mathrm{CI}=0.96-2.22, \mathrm{p}=0.074$ ), indicating that $A P C$ promoter methylation may play an important role in male patients with bladder cancer. More studies with large sample sizes are needed to further confirm whether APC promoter methylation is linked to age, lymph node status, and tumor number of bladder cancer.

Heterogeneity was measured in bladder cancer vs. non-malignant tissues and non-malignant blood samples $(\mathrm{p}=0.043, \mathrm{p}=0.002$, respectively). A sensitivity analysis was performed to observe the influence of a single study on the OR and heterogeneity by omitting one study. We removed one study [35] in cancer vs. non-malignant tissues, and one study [36] in cancer vs. non-malignant blood samples. The results remained significant, with no evidence of substantial heterogeneity, suggesting the stability of the results. Moreover, study quality was estimated using the NOS, giving validity to the results of the current meta-analysis.

Several limitations should be stated in this meta-analysis. First, Egger's test showed a slight publication bias between $A P C$ promoter methylation and tumor stage $(\mathrm{p}=0.025)$. The publications with positive results are more easily published than publications with negative results. Papers published only in English or Chinese language were selected in the current meta-analysis, which might lead to a slight publication bias. Second, based on small population, more studies regarding the results of the Asian population and non-MSP subgroups are necessary in the future. Third, only two studies involving blood samples were analyzed in this meta-analysis. Finally, only one study reported that $A P C$ promoter methylation was not linked to the prognosis of patients with bladder cancer using multivariate analysis. More researches with a large population are essential to further validate the prognostic role of $A P C$ promoter methylation.

In conclusion, our results suggest that $A P C$ promoter methylation is correlated with bladder cancer in tissue and urine samples, but not associated with bladder cancer in the blood. Promoter methylation of the APC gene was associated with gender, clinical stage, and tumor grade, but not linked to age, lymph node status, tumor number, and the prognosis of bladder cancer in overall survival. Further large-scale studies with large population should be performed in the future.

Supplementary information is available in the online version of the paper.

\section{References}

[1] SIEGEL RL, MILLER KD, JEMAL A. CA Cancer J Clin 2017; 67: 7-30. https://doi.org/10.3322/caac.21387
[2] TORRE LA, BRAY F, SIEGEL RL, FERLAY J, LORTETTIEULENT J et al. Global cancer statistics, 2012. CA Cancer J Clin 2015; 65: 87-108. https://doi.org/10.3322/caac.21262

[3] BABJUK M, BOHLE A, BURGER M, CAPOUN O, COHEN $D$ et al. EAU Guidelines on Non-Muscle-invasive Urothelial Carcinoma of the Bladder: Update 2016. Eur Urol 2017; 71: 447-461. https://doi.org/10.1016/j.eururo.2016.05.041

[4] SOLOWAY MS. Bladder cancer: Lack of progress in bladder cancer-what are the obstacles? Nat Rev Urol 2013; 10: 5-6. https://doi.org/10.1038/nrurol.2012.219

[5] PROUT GR JR, BARTON BA, GRIFFIN PP, FRIEDELL GH. Treated history of noninvasive grade 1 transitional cell carcinoma. The National Bladder Cancer Group. J Urol 1992; 148: 1413-1419.

[6] OKUGAWA Y, GRADY WM, GOEL A. Epigenetic Alterations in Colorectal Cancer: Emerging Biomarkers. Gastroenterology 2015; 149: 1204-1225. https://doi.org/10.1053/j. gastro.2015.07.011

[7] GHAVIFEKR FAKHR M, FARSHDOUSTI HAGH M, SHANEHBANDI D, BARADARAN B. DNA methylation pattern as important epigenetic criterion in cancer. Genet Res Int 2013; 2013: 317569. https://doi.org/10.1155/2013/317569

[8] DUMITRESCU RG. Epigenetic markers of early tumor development. Methods Mol Biol 2012; 863: 3-14. https://doi. org/10.1007/978-1-61779-612-8_1

[9] YE M, HUANG T, NI C, YANG P, CHEN S. Diagnostic Capacity of RASSF1A Promoter Methylation as a Biomarker in Tissue, Brushing, and Blood Samples of Nasopharyngeal Carcinoma. EBioMedicine 2017; 18: 32-40. https://doi. org/10.1016/j.ebiom.2017.03.038

[10] MISAWA K, MOCHIZUKI D, IMAI A, ENDO S, MIMA $\mathrm{M}$ et al. Prognostic value of aberrant promoter hypermethylation of tumor-related genes in early-stage head and neck cancer. Oncotarget 2016; 7: 26087-26098. https://doi. org/10.18632/oncotarget.8317

[11] CUI C, GAN Y, GU L, WILSON J, LIU Z et al. P16-specific DNA methylation by engineered zinc finger methyltransferase inactivates gene transcription and promotes cancer metastasis. Genome Biol 2015; 16: 252. https://doi.org/10.1186/ s13059-015-0819-6

[12] HULBERT A, JUSUE-TORRES I, STARK A, CHEN C, RODGERS $\mathrm{K}$ et al. Early Detection of Lung Cancer Using DNA Promoter Hypermethylation in Plasma and Sputum. Clin Cancer Res 2017; 23: 1998-2005. https://doi. org/10.1158/1078-0432.CCR-16-1371

[13] QUILLIEN V, LAVENU A, DUCRAY F, JOLY MO, CHINOT O et al. Validation of the high-performance of pyrosequencing for clinical MGMT testing on a cohort of glioblastoma patients from a prospective dedicated multicentric trial. Oncotarget 2016; 7: 61916-61929. https://doi.org/10.18632/ oncotarget.11322

[14] FRIEDRICH A, KULLMANN F. [Familial adenomatous polyposis syndrome (FAP): pathogenesis and molecular mechanisms]. Med Klin (Munich) 2003; 98: 776-782. https://doi.org/10.1007/s00063-003-1325-2

[15] KINZLER KW, NILBERT MC, SU LK, VOGELSTEIN B, BRYAN TM et al. Identification of FAP locus genes from chromosome 5q21. Science 1991; 253: 661-665. https://doi. org/10.1126/science.1651562 
[16] ACETO GM, FANTINI F, DE IURE S, DI NICOLA M, PALKA G et al. Correlation between mutations and mRNA expression of APC and MUTYH genes: new insight into hereditary colorectal polyposis predisposition. J Exp Clin Cancer Res 2015; 34: 131. https://doi.org/10.1186/s13046015-0244-4

[17] KAMORY E, OLASZ J, CSUKA O. Somatic APC inactivation mechanisms in sporadic colorectal cancer cases in Hungary. Pathol Oncol Res 2008; 14: 51-56. https://doi. org/10.1007/s12253-008-9019-y

[18] FODDE R, KUIPERS J, ROSENBERG C, SMITS R, KIELMAN $\mathrm{M}$ et al. Mutations in the APC tumour suppressor gene cause chromosomal instability. Nat Cell Biol 2001; 3: 433-438. https://doi.org/10.1038/35070129

[19] PIETRUSINSKI M, KEPCZYNSKI L, JEDRZEJCZYK A, BORKOWSKA E, TRACZYK-BORSZYNSKA $M$ et al. Detection of bladder cancer in urine sediments by a hypermethylation panel of selected tumor suppressor genes. Cancer Biomark 2017; 18: 47-59. https://doi.org/10.3233/CBM-160673

[20] HAUSER S, KOGEJ M, FECHNER G, VON PEZOLD J, VORREUTHER R et al. Serum DNA hypermethylation in patients with bladder cancer: results of a prospective multicenter study. Anticancer Res 2013; 33: 779-784.

[21] BERRADA N, AMZAZI S, AMEZIANE EL HASSANI R, BENBACER L, EL MZIBRI $M$ et al. Epigenetic alterations of adenomatous polyposis coli (APC), retinoic acid receptor beta (RARbeta) and survivin genes in tumor tissues and voided urine of bladder cancer patients. Cell Mol Biol (Noisy-le-grand) 2012; Suppl. 58: OL1744-1751.

[22] PU RT, LAITALA LE, CLARK DP. Methylation profiling of urothelial carcinoma in bladder biopsy and urine. Acta Cytol 2006; 50: 499-506. https://doi.org/10.1159/000326003

[23] STANG A. Critical evaluation of the Newcastle-Ottawa scale for the assessment of the quality of nonrandomized studies in meta-analyses. Eur J Epidemiol 2010; 25: 603-605. https:// doi.org/10.1007/s10654-010-9491-Z

[24] HAN S, HUANG T, LI W, LIU S, YANG W et al. Association Between Hypoxia-Inducible Factor-2alpha (HIF-2alpha) Expression and Colorectal Cancer and Its Prognostic Role: a Systematic Analysis. Cell Physiol Biochem 2018; 48: 516527. https://doi.org/10.1159/000491806

[25] ZINTZARAS E, IOANNIDIS JP. HEGESMA: genome search meta-analysis and heterogeneity testing. Bioinformatics 2005; 21: 3672-3673. https://doi.org/10.1093/bioinformatics/bti536

[26] LAU J, IOANNIDIS JP, SCHMID CH. Quantitative synthesis in systematic reviews. Ann Intern Med 1997; 127: 820826. https://doi.org/10.7326/0003-4819-127-9-19971101000008

[27] EGGER M, DAVEY SMITH G, SCHNEIDER M, MINDER C. Bias in meta-analysis detected by a simple, graphical test. BMJ 1997; 315: 629-634. https://doi.org/10.1136/ bmj.315.7109.629

[28] BILGRAMI SM, QURESHI SA, PERVEZ S, ABBAS F. Promoter hypermethylation of tumor suppressor genes correlates with tumor grade and invasiveness in patients with urothelial bladder cancer. Springerplus 2014; 3: 178. https:// doi.org/10.1186/2193-1801-3-178
[29] EISSA S, SWELLAM M, EL-KHOULY IM, KASSIM SK, SHEHATA $\mathrm{H}$ et al. Aberrant methylation of RARbeta2 and APC genes in voided urine as molecular markers for early detection of bilharzial and nonbilharzial bladder cancer. Cancer Epidemiol Biomarkers Prev 2011; 20: 1657-1664. https://doi.org/10.1158/1055-9965.EPI-11-0237

[30] CHEN PC, TSAI MH, YIP SK, JOU YC, NG CF et al. Distinct DNA methylation epigenotypes in bladder cancer from different Chinese sub-populations and its implication in cancer detection using voided urine. BMC Med Genomics 2011; 4: 45. https://doi.org/10.1186/1755-8794-4-45

[31] SERIZAWA RR, RALFKIAER U, STEVEN K, LAM GW, SCHMIEDEL $S$ et al. Integrated genetic and epigenetic analysis of bladder cancer reveals an additive diagnostic value of FGFR3 mutations and hypermethylation events. Int J Cancer 2011; 129: 78-87. https://doi.org/10.1002/ijc.25651

[32] RENARD I, JONIAU S, VAN CLEYNENBREUGEL B, COLLETTE C, NAOMR C et al. Identification and validation of the methylated TWIST1 and NID2 genes through real-time methylation-specific polymerase chain reaction assays for the noninvasive detection of primary bladder cancer in urine samples. Eur Urol 2010; 58: 96-104. https://doi. org/10.1016/j.eururo.2009.07.041

[33] ELLINGER J, EL KASSEM N, HEUKAMP LC, MATTHEWS S, CUBUKLUOZ et al. Hypermethylation of cellfree serum DNA indicates worse outcome in patients with bladder cancer. J Urol 2008; 179: 346-352. https://doi. org/10.1016/j.juro.2007.08.091

[34] YATES DR, REHMAN I, ABBOD MF, MEUTH M, CROSS SS et al. Promoter hypermethylation identifies progression risk in bladder cancer. Clin Cancer Res 2007; 13: 2046-2053. https://doi.org/10.1158/1078-0432.CCR-06-2476

[35] NEUHAUSEN A, FLORL AR, GRIMM MO, SCHULZ WA. DNA methylation alterations in urothelial carcinoma. Cancer Biol Ther 2006; 5: 993-1001.

[36] YATES DR, REHMAN I, MEUTH M, CROSS SS, HAMDY FC et al. Methylational urinalysis: a prospective study of bladder cancer patients and age stratified benign controls. Oncogene 2006: 25: 1984-1988. https://doi.org/10.1038/ sj.onc.1209209

[37] DULAIMI E, UZZO RG, GREENBERG RE, AL-SALEEM T, CAIRNS P. Detection of bladder cancer in urine by a tumor suppressor gene hypermethylation panel. Clin Cancer Res 2004; 10: 1887-1893. https://doi.org/10.1158/1078-0432. CCR-03-0127

[38] MARUYAMA R, TOYOOKA S, TOYOOKA KO, HARADA $\mathrm{K}$, VIRMANI AK et al. Aberrant promoter methylation profile of bladder cancer and its relationship to clinicopathological features. Cancer Res 2001; 61: 8659-8663.

[39] PAN J, CHEN LW, WANG WW, HU QU, WANG SZ. [Clinical Implications of Methylation Status of Apaf-1 and APC Gene in Bladder Carcinoma]. Journal of Sun Yat-Sen University (Medical Sciences) 2010; 31: 397-400.

[40] TANG Z, LI C, KANG B, GAO G, LI C et al. GEPIA: a web server for cancer and normal gene expression profiling and interactive analyses. Nucleic Acids Res 2017; 45: W98W102. https://doi.org/10.1093/nar/gkx247 
[41] BRAIT M, LOYO M, ROSENBAUM E, OSTROW KL, MARKOVA A et al. Correlation between BRAF mutation and promoter methylation of TIMP3, RARbeta2 and RASSF1A in thyroid cancer. Epigenetics 2012; 7: 710-719. https:// doi.org/10.4161/epi.20524

[42] SHARMA S, SALEHI F, SCHEITHAUER BW, ROTONDO F, SYRO LV et al. Role of MGMT in tumor development, progression, diagnosis, treatment and prognosis. Anticancer Res 2009; 29: 3759-3768.

[43] HERMAN JG, BAYLIN SB. Promoter-region hypermethylation and gene silencing in human cancer. Curr Top Microbiol Immunol 2000; 249: 35-54.

[44] YE M, HUANG T, YING Y, LI J, YANG P et al. Detection of 14-3-3 sigma (sigma) promoter methylation as a noninvasive biomarker using blood samples for breast cancer diagnosis. Oncotarget 2017; 8: 9230-9242. https://doi.org/10.18632/ oncotarget.13992

[45] HUBERS AJ1, HEIDEMAN DA1, BURGERS SA2, HERDER GJ3, STERK PJ et al. DNA hypermethylation analysis in sputum for the diagnosis of lung cancer: training validation set approach. Br J Cancer 2015; 112: 1105-1113, https://doi. org/10.1038/bjc.2014.636
[46] CHEN F, HUANG T, REN Y, WEI J, LOU Z et al. Clinical significance of $\mathrm{CDH} 13$ promoter methylation as a biomarker for bladder cancer: a meta-analysis. BMC Urol 2016; 16: 52. https://doi.org/10.1186/s12894-016-0171-5

[47] DAI L, MA C, ZHANG Z, ZENG S, LIU A et al. DAPK Promoter Methylation and Bladder Cancer Risk: A Systematic Review and Meta-Analysis. PLoS One 2016; 11: e0167228. https://doi.org/10.1371/journal.pone.0167228

[48] FANTONY JJ, ABERN MR, GOPALAKRISHNA A, OWUSU R, JACK TAY K et al. Multi-institutional external validation of urinary TWIST1 and NID2 methylation as a diagnostic test for bladder cancer. Urol Oncol 2015; 33: 387. e381-386. https://doi.org/10.1016/j.urolonc.2015.04.014

[49] SANCHEZ-CARBAYO M. Urine epigenomics: a promising path for bladder cancer diagnostics. Expert Rev Mol Diagn 2012; 12: 429-432. https://doi.org/10.1586/erm.12.42

[50] PHE V, CUSSENOT O, ROUPRET M. Interest of methylated genes as biomarkers in urothelial cell carcinomas of the urinary tract. BJU Int 2009; 104: 896-901. https://doi. org/10.1111/j.1464-410X.2009.08696.x

[51] Lopez-Beltran A. Bladder cancer: clinical and pathological profile. Scand J Urol Nephrol Suppl 2008; 218: 95-109. https://doi.org/10.1080/03008880802325226 


\section{$A P C$ promoter methylation is correlated with development and progression of bladder cancer, but not linked to overall survival: a meta-analysis}

Z. J. BAI ${ }^{1}$, Q. LIU ${ }^{1}$, X. S. WANG ${ }^{1}$, W. Y. LIU $2, *$

Supplemental material

Supplementary Table 1. General characteristics of the included studies with clinical features.

\begin{tabular}{|c|c|c|c|c|c|c|c|c|c|c|c|c|c|c|c|c|c|}
\hline \multirow[t]{2}{*}{ First author } & \multirow[t]{2}{*}{ Country } & \multirow[t]{2}{*}{ Ethnicity } & \multirow[t]{2}{*}{ Method } & \multirow[t]{2}{*}{ Sample } & Cancer & Male & Female & $\begin{array}{c}>60 \\
\text { years } \\
\end{array}$ & $\begin{array}{c}<60 \\
\text { years } \\
\end{array}$ & $\begin{array}{c}\text { Grade } \\
3-4 \\
\end{array}$ & $\begin{array}{c}\text { Grade } \\
1-2 \\
\end{array}$ & \multirow{2}{*}{$\begin{array}{c}\text { Stage } \\
2-4 \\
M / N\end{array}$} & \multirow{2}{*}{$\begin{array}{c}\begin{array}{c}\text { Stage } \\
\text { Ta-1 }\end{array} \\
\mathrm{M} / \mathrm{N}\end{array}$} & \multirow{2}{*}{$\begin{array}{c}\text { Single } \\
\mathrm{M} / \mathrm{N}\end{array}$} & \multirow{2}{*}{$\begin{array}{c}\text { Multiple } \\
\mathrm{M} / \mathrm{N}\end{array}$} & \multirow{2}{*}{$\begin{array}{c}\text { Node+ } \\
\mathrm{M} / \mathrm{N}\end{array}$} & \multirow{2}{*}{$\begin{array}{l}\text { Node- } \\
M / N\end{array}$} \\
\hline & & & & & N (M \%) & $\mathrm{M} / \mathrm{N}$ & $\mathrm{M} / \mathrm{N}$ & $\mathrm{M} / \mathrm{N}$ & $\mathbf{M} / \mathbf{N}$ & $\mathrm{M} / \mathrm{N}$ & $\mathbf{M} / \mathbf{N}$ & & & & & & \\
\hline Maruyama 2001 & USA & Caucasians & MSP & Tissue & $98(34.7)$ & & & & & $28 / 65$ & $6 / 32$ & & & & & & \\
\hline Dulaimi 2004 & USA & Caucasians & MSP & Tissue & $45(68.9)$ & $24 / 33$ & $7 / 12$ & $22 / 35$ & $9 / 10$ & $14 / 22$ & $15 / 21$ & $13 / 17$ & $18 / 28$ & & & $4 / 5$ & $27 / 40$ \\
\hline Dulaimi 2004 & USA & Caucasians & MSP & Urine & $45(55.6)$ & $20 / 33$ & $5 / 12$ & $17 / 35$ & $8 / 10$ & $11 / 22$ & $13 / 21$ & $10 / 17$ & $15 / 28$ & & & $3 / 5$ & $22 / 40$ \\
\hline Neuhausen 2006 & Germany & Caucasians & MSP & Tissue & $96(44.8)$ & & & & & $31 / 64$ & $12 / 32$ & $40 / 80$ & $3 / 16$ & & & $13 / 22$ & $30 / 74$ \\
\hline Pan 2010 & China & Asians & MSP & Tissue & $110(82.7)$ & $66 / 78$ & $25 / 32$ & $61 / 70$ & $30 / 40$ & $49 / 50$ & $42 / 60$ & $60 / 62$ & $31 / 48$ & $51 / 65$ & $40 / 45$ & $23 / 27$ & $68 / 83$ \\
\hline Eissa 2011 & Egypt & Caucasians & MSP & Urine & $210(59.5)$ & $86 / 145$ & $39 / 65$ & & & $36 / 57$ & $89 / 153$ & $80 / 133$ & $45 / 77$ & & & & \\
\hline Serizawa 2011 & Denmark & Caucasians & MethyLight & Tissue & $105(30.5)$ & $28 / 80$ & $4 / 25$ & $24 / 84$ & $8 / 21$ & $21 / 50$ & $10 / 54$ & $12 / 19$ & $20 / 86$ & $22 / 73$ & $9 / 31$ & & \\
\hline Chen 2011 & China & Asians & MSP & Tissue & $210(35.7)$ & & & & & & & $26 / 55$ & $49 / 155$ & & & & \\
\hline Berrada 2012 & Morocco & Caucasians & MSP & Tissue & $29(100)$ & $25 / 25$ & $4 / 4$ & $16 / 16$ & $5 / 5$ & $18 / 18$ & $9 / 9$ & $5 / 5$ & $22 / 22$ & & & & \\
\hline Berrada 2012 & Morocco & Caucasians & MSP & Urine & $29(79.3)$ & $21 / 25$ & $2 / 4$ & $13 / 16$ & $2 / 5$ & $17 / 18$ & $4 / 9$ & $5 / 5$ & $16 / 22$ & & & & \\
\hline Bilgrami 2014 & Pakistan & Caucasians & MSP & Tissue & $76(71.1)$ & & & & & & & $32 / 33$ & $22 / 43$ & & & & \\
\hline Pietrusiński 2017 & Poland & Caucasians & MSP & Urine & $113(46)$ & & & & & $29 / 52$ & $25 / 61$ & $15 / 23$ & $39 / 90$ & & & & \\
\hline
\end{tabular}

MSP: methylation-specific polymerase chain reaction; M: methylation; N: sample size; Node: lymph node status. 